\title{
Folic-acid Deficiency and Megaloblastic Erythropoiesis in Myelofibrosis
}

\author{
J. FORSHAW,* M.A., M.D., M.R.C.P. ; LILIAN HARWOOD, † F.I.M.L.T. \\ DAVID J. WEATHERALL, $\ddagger$ M.D., M.R.C.P.
}

Brit. med.F., 1964, 1, 671-672

Folic-acid deficiency may arise in conditions which produce an increased demand for the vitamin. Diseases in this category include acute leukaemia, disseminated carcinomatosis (Girdwood, 1959), myelofibrosis (Chanarin, Mollin, and Anderson, 1958), and haemolytic anaemia (Chanarin, Dacie, and Mollin, 1959). The presence of megaloblastic erythropoiesis in myelofibrosis has been described in only a few cases and is not mentioned in recent reviews of the disease (Leonard, Israëls, and Wilkinson, 1957 ; Bowdler and Prankerd, 1961; Wintrobe, 1961 ; Brit. med. $₹ ., 1963$ ). Chanarin et al. (1958) studied five patients with chronic myelofibrosis, in all of whom there was rapid clearance from the plasma of injected folic acid and in one patient there was a megaloblastic bone-marrow picture. The occurrence of megaloblastic erythropoiesis due to vitamin- $B_{12}$ deficiency has also been described in three patients with myelofibrosis (Croft, 1956; Baikie, Cunningham, and McAlpine, 1958 ; Wellington and Whitcomb, 1960).

We describe here three cases of myelofibrosis in which there was megaloblastic erythropoiesis produced by folic-acid deficiency. One of these patients developed polycythaemia after receiving treatment with folic acid and iron.

\section{Methods}

The serum-vitamin- $B_{12}$ level was estimated by the Lactobacillus leichmannii method (Meynell, Cooke, Cox, and Gaddie, 1957), with cyanide extraction (Matthews, 1962), which gives a normal range of 140 to $850 \mu \mu \mathrm{g} . / \mathrm{ml}$.

The absorption of vitamin $B_{12}$ was studied by measuring the percentage of radioactivity of an oral dose of ${ }^{58} \mathrm{Co}$-labelled vitamin $B_{12}$ excreted in the urine in 24 hours (Schilling, 1953) (normal range: 6 to $20 \%$ of administered radioactivity excreted in the urine).

Folic-acid absorption was estimated by measuring the percentage of radioactivity of an oral dose of $0.2 \mathrm{mg}$. of folic-acid labelled with $\mathrm{H}^{3}$ excreted in the urine in 24 hours (Anderson, Belcher, Chanarin, and Mollin, 1960). The patients were previously saturated with folic-acid by giving $15 \mathrm{mg}$. of folic acid intramuscularly daily for four days, the last dose 48 hours before the test. An excretion of over $25 \%$ of the administered radioactivity indicates normal absorption.

The histidine-loading test for folic-acid deficiency was carried out according to the method described by Kohn, Mollin, and Rosenbach (1961). Leucocyte alkaline phosphatase activity was estimated by the cytochemical technique described by Hayhoe and Quaglino (1958).

\section{Case 1}

A woman aged 75 was first seen in June 1962 complaining of pallor, anorexia, and breathlessness on exertion for six months. She had never taken barbiturates or any other anticonvulsant drugs.

* Consultant Physician, Sefton General Hospital, Liverpool.

† Senior Technician, Haematology Laboratory, Sefton General Hospital, Liverpool.

‡ Senior Medical Registrar, Liverpool Royal Infirmary. (Present address : Department of Haematology, Johns Hopkins University School of Medicine, Baltimore, Maryland, U.S.A.)
The spleen was enlarged to $14 \mathrm{~cm}$. and the liver to $3 \mathrm{~cm}$. below the costal margin.

Investigations.-Haemoglobin, $4.8 \mathrm{~g} .1100 \mathrm{ml}$. ; leucocytes, $2,150 /$ c.mm. (neutrophils $44 \%$, lymphocytes $47 \%$, monocytes $6 \%$, eosinophils $2 \%$, basophils $1 \%$ ) ; platelets, 35,000/c.mm. ; reticulocytes, $3 \%$. The stained film showed anisocytosis, poikilocytosis, and macrocytosis of the red cells with a moderate number of megaloblasts and normoblasts. No marrow was obtained from sternal puncture on two occasions. Surgical biopsy of the iliac crest showed a cellular marrow containing numerous large multinucleate cells and silver stains revealed intensive infiltration with reticulin. The direct Coombs test was negative. The serumvitamin-B $\mathrm{B}_{12}$ level was $180 \mu \mu \mathrm{g} . / \mathrm{ml}$. In the vitamin-B $\mathrm{B}_{13}$-absorption test $16 \%$ of the administered radioactivity was excreted in the urine in 24 hours, and in the folic-acid-absorption test $48 \%$ of the administered radioactivity was excreted. The leucocyte alkaline phosphatase activity was normal. Faecal fat excretion over a period of five days averaged $1 \mathrm{~g}$. in 24 hours. Radiographs of the skeleton and gastro-intestinal tract were normal.

Treatment and Progress.-A single injection of $100 \mu \mathrm{g}$. of vitamin $B_{12}$ produced a reticulocyte response of $16 \%$. An injection of $1,000 \mu \mathrm{g}$. of vitamin $\mathrm{B}_{12}$ was then given as a flushing dose in the vitamin- $B_{12}$-absorption test, and four weeks later the haemoglobin level was $9.8 \mathrm{~g} . / 100 \mathrm{ml}$., the leucocytes $7,350 / \mathrm{c} . \mathrm{mm}$., and the platelets $360,000 / \mathrm{c} . \mathrm{mm}$. ; the stained blood film now showed that most of the red cells were microcytic and normochromic and there was marked polychromasia. At this stage the histidine-loading test showed a moderate amount of formiminoglutamic acid (Figlu) in the urine. Treatment with folic acid $15 \mathrm{mg}$. daily by mouth was started; this did not produce any reticulocyte response and after three weeks there was no change in the haemoglobin level. The serum iron and total iron-binding capacity were $27 \mu \mathrm{g}$. and $305 \mu \mathrm{g}$./ $100 \mathrm{ml}$. respectively, and in view of these results oral iron was given in addition to folic acid. One month later the haemoglobin had risen to $12.1 \mathrm{~g} . / 100 \mathrm{ml}$. In June 1963 she was free from symptoms and had gained $8 \mathrm{lb}$. $(3.6 \mathrm{~kg}$.) in weight. There was no change in the size of the liver and spleen. The haemoglobin level was 11.3 g. $/ 100 \mathrm{ml}$, the leucocytes numbered $2,500 / \mathrm{c} . \mathrm{mm}$., and the serumvitamin-B 12 level was $390 \mu \mu \mathrm{g} . / \mathrm{ml}$.

\section{Case 2}

A woman aged 78 was admitted to hospital in January 1963 with a history of lassitude, breathlessness on exertion, angina pectoris, and a sore mouth and tongue for one year. Her appetite was good and she had not lost any weight. She had not been taking barbiturates or any other anticonvulsant drugs. On examination she had glossitis and the spleen was enlarged to $15 \mathrm{~cm}$. and the liver to $3 \mathrm{~cm}$. below the costal margin.

Investigations.-Haemoglobin, $6.7 \mathrm{~g} . / 100 \mathrm{ml}$; leucocytes, $13,800 /$ c.mm. (neutrophils $77 \%$, lymphocytes $10 \%$, monocytes $1 \%$, eosinophils $3 \%$, basophils $1 \%$, myelocytes $7 \%$, blast cells $1 \%$ ); platelets $126,000 /$ c.mm.; reticulocytes $3 \%$. The stained film showed marked anisocytosis, poikilocytosis, polychromasia, and hypochromia of the red cells and there were a large number of normoblasts. The aspirate obtained by sternal puncture was hypocellular and did not contain any abnormal cells. Surgical biopsy of the iliac crest showed a cellular marrow containing a moderate number of fibroblasts, and silver stains revealed an intensive infiltration with reticulin. The direct Coombs test was negative. The serum-vitamin- $B_{12}$ level was $900 \mu \mu \mathrm{g} . / \mathrm{ml}$. In the histidineloading test there was a moderate amount of Figlu in the urine. In the folic-acid-absorption test the 24-hour collection of urine was incomplete owing to the poor co-operation of the patient, but $26 \%$ 
of the administered radioactivity was present in the urine available. The serum iron was $30 \mu \mathrm{g}$. and the total iron-binding capacity $450 \mu \mathrm{g} . / 100 \mathrm{ml}$. The leucocyte alkaline phosphatase activity was increased. The serum uric acid was $10.4 \mathrm{mg} . / 100 \mathrm{ml}$. Occult blood tests on the stools were negative. The faecal fat excretion over a period of three days averaged $1.4 \mathrm{~g}$. in 24 hours. Skeletal $x$-ray films showed slight generalized osteoporosis, and radiographs of the gastro-intestinal tract were normal.

Treatment and Progress.-After two weeks' treatment with ferrous sulphate the haemoglobin level had risen to $8.1 \mathrm{~g} . / 100 \mathrm{ml}$. and the stained blood film contained numerous megaloblasts. Treatment with folic acid $15 \mathrm{mg}$. daily by mouth was then started; this did not produce a reticulocyte response, the reticulocytes remaining between 5 and $7 \%$ from the first day of treatment, but during the next two weeks the haemoglobin rose to $11.6 \mathrm{~g} . / 100 \mathrm{ml}$. She continued taking iron and folic acid, and three months later her complexion was florid and she complained of headache. The haemoglobin was 17.5 g. $/ 100 \mathrm{ml}$., the erythrocytes 7,470,000/c.mm., leucocytes $18,150 /$ c.mm. (neutrophils $80 \%$ ), and platelets 196,000/ c.mm. The serum-vitamin-B 12 level was $1,000 \mu \mu \mathrm{g} . / \mathrm{ml}$. Treatment with iron and folic acid was then stopped and one month later the haemoglobin was $18.6 \mathrm{~g} . / 100 \mathrm{ml}$., erythrocytes 9,480,000/c.mm., and leucocytes $22,050 / \mathrm{c} . \mathrm{mm}$.

\section{Case 3}

A 68-year-old woman, who was admitted to hospital in January 1963, complained of lassitude, pruritus, and swelling of the fingers, with extrusion of a chalky material during the previous year. Her appetite had not been impaired and she had not received any barbiturate or anticonvulsant therapy. Clinical examination revealed pallor, marked splenomegaly, and a gouty arthritis of her hands.

Investigations.-Haemoglobin, 9.9 g./100 ml. ; leucocytes, 5,000/ c.mm. (neutrophils $52 \%$, lymphocytes $35 \%$, monocytes $11 \%$, myelocytes $1 \%$, blast cells $1 \%$ ); reticulocytes $2 \%$. The stained film showed marked anisocytosis, poikilocytosis, and hypochromia of the red cells, a moderate number of normoblasts, numerous giant platelets, and a few megakaryocyte fragments. The material obtained by sternal-marrow puncture was scanty and hypocellular, but it contained a few megaloblasts. Surgical biopsy of the iliac crest revealed a marked increase in reticulum cells, and silver stains showed a moderate infiltration with reticulin. The serum-vitaminB $_{12}$ level was $240 \mu \mu \mathrm{g} . / \mathrm{ml}$. After a loading dose of histidine a moderate amount of Figlu was present in the urine. In the folicacid-absorption test $60 \%$ of the administered radioactivity was excreted in the urine. The leucocyte alkaline phosphatase activity was normal. The serum uric acid was $6 \mathrm{mg} . / 100 \mathrm{ml}$. The faecal fat excretion over a five-day period averaged $4.8 \mathrm{~g}$. in 24 hours. Radiographs of the skeleton and gastro-intestinal tract were normal.

Treatment and Progress.-There was no response to treatment with oral iron. Treatment with folic acid did not produce a reticulocyte response, but after 10 weeks the haemoglobin had risen to $10.9 \mathrm{~g} . / 100 \mathrm{ml}$.

\section{Discussion}

Megaloblastic erythropoiesis in myelofibrosis has been attributed to the large demand for folic acid and also to malabsorption of folic acid and vitamin $B_{12}$ (Chanarin et al., 1958). In our three patients the association of a positive histidine-loading test with a normal or raised serum-vitamin- $B_{12}$ level confirmed that the megaloblastic erythropoiesis was produced by folic-acid deficiency. All three patients had normal folic-acid absorption and therefore the folic-acid deficiency probably resulted entirely from excessive utilization of the vitamin.

Two of the patients also had severe iron-deficiency without evidence of bleeding, and in one of these patients the megaloblasts appeared in the peripheral blood only after iron therapy. This observation supports the view of Herbert (1959a) that the features of folic-acid and vitamin- $B_{12}$ deficiency in the peripheral blood may be masked by concomitant iron deficiency.

The presence of folic-acid deficiency and megaloblastic erythropoiesis in three consecutive patients with myelofibrosis suggests that this may occur more often than has been supposed. The recognition of folic-acid and iron deficiency is of considerable practical importance, because under these circumstances specific haematinic therapy should be tried before therapy with drugs, such as androgens, steroids, and busulphan.

One of our patients who was severely anaemic responded to an initial injection of $100 \mu \mathrm{g}$. of vitamin $\mathrm{B}_{12}$ despite a normal serum-vitamin- $\mathrm{B}_{12}$ absorption. In our experience, however, it is not uncommon for patients with folic-acid deficiency to respond to vitamin $B_{12}$. In the other patient with severe anaemia initial treatment with iron produced a rapid rise in the haemoglobin level accompanied by the appearance of megaloblasts in the peripheral blood ; on further treatment with iron and folic acid she developed polycythaemia, which continued to progress after treatment was stopped.

The association of polycythaemia vera with myelofibrosis is well recognized (Bowdler and Prankerd, 1961), but the majority of cases have presented with polycythaemia and developed myelofibrosis and anaemia subsequently. Croft (1956) and Baikie et al. (1958), however, have reported two cases of patients with myelofibrosis and low serum-vitamin- $B_{12}$ levels who developed polycythaemia after treatment with vitamin $\mathbf{B}_{12}$. Furthermore, some of the reported cases of alleged pernicious anaemia that developed polycythaemia after vitamin-B ${ }_{12}$ treatment (Galt, Hunter, and Hill, 1952 ; Skouby, 1952 ; Hinz, 1957) did not have the diagnosis confirmed by vitamin- $\mathrm{B}_{12}$-absorption tests and could have been cases of myelofibrosis. Folic-acid deficiency and megaloblastic erythropoiesis have been observed in patients with polycythaemia vera (Herbert, 1959b), but we know of no other reported case in which the development of polycythaemia vera was prevented by iron and folic-acid deficiency.

\section{Summary}

Three cases of myelofibrosis are described which demonstrate the importance of the recognition of folic-acid and iron deficiency in this condition. Folic-acid absorption was normal in these patients, and it is concluded that the folic-acid deficiency resulted from an increased utilization of the vitamin. One patient developed polycythaemia after treatment with folic acid and iron, and the relation between polycythaemia and myelofibrosis is briefly reviewed.

We wish to thank Dr. W. Kulke and the staff of the Radioactive Isotope Department, Liverpool Radium Institute, for carrying out the vitamin-B $B_{12-}$ and folic-acid-absorption tests; Dr. E. H. Moorhouse and Dr. J. A. Edwards for their help; and Mr. J. Howell Hughes for permission to publish Case 3 .

REFERENCES

Anderson, B., Belcher, E. H., Chanarin, I., and Mollin, D. L. (1960).

Brit. F. Haemat., 6, 439. T. A., and McAlpine, S. G. (1958). Scot. med. 7 ., $3,26$.

Bowdler, A. J., and Prankerd, T. A. J. (1961). Brit. med. F., 1, 1352.

Brit. med. F., $1963,1,900$. 5,245 .

Mollin, D. L., and Anderson, B. B. (1958). Proc. roy. Soc. Med., 51, 757 .

Croft, C. R. (1956). Lancet, 2, 1332.

Galt, J., Hunter, R. B., and Hill, J. M. (1952). Amer. F. med. Sci., 223, 61.

Girdwood, R. H. (1959). Brit. med. Bull., 15, 14

Hayhoe, F. G. J., and Quaglino, D. (1958). Brit. 7. Haemat., 4, 375.

Herbert, v. D. (1959a). The Megaloblastic Anaemias, p. 42. Grune and Stratton New York and London. (1959b). Ibid., p. 59.

Hinz, C. F., iun. (1957). Ann. intern. Med., 47, 544

Hinz, C. F., jun. (1957). Ann. intern. Med., M. (1961). F. clin. Path., 14, 345 .

Leonard, B. J., Israëls, M. C. G., and Wilkinson, J. F. (1957). Quart. Y. Med., 26, 131.

Matthews, D. M (1962). Clin. Sci., 22, 101. ., and Gaddie, R. (1957). Meynell, M. J., Cook Lancet, 1,901 .

Schilling, R. F. (1953). 尹. Lab. clin. Med., 42, 860

Skouby, A P. (1962). Acta med scand. 141, 244.

Wellin, A. 750.

Wintrobe, M. M. (1961). Clinical Haematology, 5th ed., p. 581. Kimpton, London. 